
UCRL-ID-114590

\title{
TENSILE PROPERTIES OF 21-6-9 STAINLESS STEEL AT ELEVATED TEMPERATURES
}

\author{
S.G. Torres \\ G.A. Henshall
}

October 1993

This is an informal report intended primarily for internal or limited external distribution. The opinions and conclusions stated are those of the author and may or may not be those of the Laboratory.

Work performed under the auspices of the U.S. Department of Energy by the Lawrence Livermore National Laboratory under Contract W-7405-Eng-48. 


\section{DISCLAIMER}

This document was prepared as an account of work sponsored by an ag sicy of the United States Government. Neither the United States Government nor the University of California nor any of their employees, makes any warranty, express or implied, or assumes any legal liabiliky or responsibility for the accuracy, completeness, or usefulness of any information, apparatus, product, or process disclosed, or represents that its use would not infringe privately owned rights. Reference herein to any specific commercial products, process, or service by trade name, trademark, manufacturer, or otherwise, does not necessarliy constitute or imply its endorsement, recommendation, or favoring by the United States Government or the University of California. The views and opinions of authors expressed herein do not necessarily state or reflect those of the United States Government or the University of Callfornia, and shall not be used for advertising or product endorsement purposes.

This report bas been reproduced directly from the best available copy.

Available to DOE and DOE contractors from the Ofrice of Scientific and Technical Information P.O. Box 62, Oak Ridge, TN 37831

Prices available from (615) 576-8401, FTS 626-8401

Available to the public from the

National Technical Information Service

US. Department of Commerce 5285 Port Royal Rd., Springfield, VA 22161 


\title{
TENSILE PROPERTIES OF 21-6-9 STAINLESS STEEL AT ELEVATED TEMPERATURES
}

\author{
S. G. Torres and G. A. Henshall
}

Abstract - The tensile properties of Type 21-6-9 austenitic stainless steel have been measured at temperatures ranging from ambient to $1200^{\circ} \mathrm{C}$ at a strain rate of $6.67 \times 10^{-4}$ $\mathrm{s}^{-1}$. The data show that the yield stress decreases rapidly with increasing temperature from room temperature to about $300^{\circ} \mathrm{C}$, followed by a nearly constant value in the "plateau" region from 300 to $600^{\circ} \mathrm{C}$. Beyond the "plateau", there is a more rapid drop in yield stress as temperature increases. The temperature dependence of the ultimate tensile stress shows a plateau between approximately 300 and $700^{\circ} \mathrm{C}$, which may be caused by the presence of solutes. 21-6-9 stainless steel has excellent ductility, with the elongation to failure ranging from 55 to $95 \%$. It appears that there is a local minimum in the ductility at approximately $700^{\circ} \mathrm{C}$.

The results from this investigation have been compared with the earlier results of Kassner and co-workers. Overall, the data compare favorably, though somewhat more pronounced plateaus in strength at intermediate temperatures and higher ductilities were measured in the present study. Small differences in the alloy composition are believed to have caused the former, while the latter is attributed to the use of shorter gage length specimens in the present study. The data gathered in this investigation will be useful to designers and analysts who wish to perform stress analyses involving 21-6-9 stainless steel at a variety of temperatures.

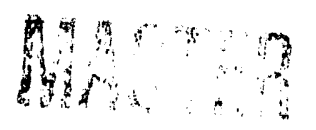




\section{Introduction}

Type 21-6-9 austenitic stainless steel is commonly used at the Lawrence Livermore National Laboratory (LLNL), and its tensile properties are of interest over a broad range of temperatures. Earlier studies by Kassner and co-workers [1-4] were performed using 21-6-9 stainless steel, examining temperatures ranging from 20 to 1100 ${ }^{\circ} \mathrm{C}$ and strain rates from $8.3 \times 10^{-5}$ to $10^{4} \mathrm{~s}^{-1}$. The focus of this earlier work was to quantify the effects of strain rate and temperature on the yield stress (YS). Only a limited amount of data was taken at any given strain rate for evaluating the ultimate tensile stress (UTS) and, especially, the elongation to failure.

The major goal of the present study was to provide data at a single quasi-static strain rate that would allow engineers to perform finite-element stress analyses for structures made from 21-6-9 stainless steel. For the constitutive models most often used at LLNL for these purposes, the YS, UTS and elongation to failure all are needed at a single strain rate over a range of temperatures. The data gathered in the present study, together with the previous data of Kassner and co-workers, will assist engineers in modeling the behavior of 21-6-9 stainless steel at elevated temperatures.

To provide the required data, tensile testing of 21-6-9 stainless steel sheet was conducted in vacuum at elevated temperatures using a nominal strain rate of $6.67 \times 10^{-4}$ $\mathrm{s}^{-1}$. In addition, room temperature tensile tests were performed at three different strain rates to deternine the strain-rate sensitivity of 21-6-9 stainless steel at ambient temperature. These results are compared with the earlier results of Kassner and coworkers.

\section{Experimental Materials and Procedures}

\section{Materials:}

The material used in this investigation was weapons grade 21-6-9 stainless steel sheet with a thickness of $6.35 \mathrm{~mm}$. The composition of this material is given in Table 1 for an annealed test specimen and a specimen following testing at $500{ }^{\circ} \mathrm{C}$. The composition presented by Kassner and co-workers [1-3] also is listed in Table 1. The microstructure of the as-received material consisted of equiaxed grains containing a high density of twins. The grain size was determined to be ASTM no. 5, which corresponds to an average diameter of approximately $60 \mu \mathrm{m}$. This material was used to machine flat pin- 
grip specimens with the geometry shown in Fig. 1. A small amount of grain growth to ASTM no. 4 ( $90 \mu \mathrm{m}$ diameter) was observed after vacuum annealing for one hour at 1070 ${ }^{\circ} \mathrm{C}$. A similar anneal, one hour at $1080^{\circ} \mathrm{C}$, was performed on machined specimens prior to testing. As shown in Fig. 2, a high density of twins was still present within the equiaxed grains following annealing. No additional grain growth was observed following tensile testing, even for tests performed at $1200^{\circ} \mathrm{C}$.

Table 1. Chemical composition of Type 21-6-9 Stainless Steel.

Values are given in weight percent.

\begin{tabular}{cccc}
\hline Element & Annealed & Tested at $500^{\circ} \mathrm{C}$ & Kassner [1-3] \\
\hline $\mathrm{C}$ & 0.030 & 0.033 & 0.02 \\
$\mathrm{O}$ & 0.003 & 0.002 & not reported \\
$\mathrm{N}$ & 0.279 & 0.282 & 0.30 \\
$\mathrm{Cr}$ & 19.52 & 19.74 & 19.81 \\
$\mathrm{Mn}$ & 8.73 & 8.69 & 9.38 \\
$\mathrm{Ni}$ & 7.49 & 7.49 & 7.23 \\
$\mathrm{Si}$ & 0.34 & 0.34 & 0.09 \\
$\mathrm{P}$ & 0.021 & 0.021 & 0.011 \\
$\mathrm{~S}$ & $<0.005$ & $<0.005$ & 0.01 \\
$\mathrm{Fe}$ & bal. & bal. & bal. \\
\hline
\end{tabular}

\section{Equipment and Procedures:}

Tensile testing of the 21-6-9 stainless steel sheet specimens was performed in a 457.2-mm diameter Brew Front-Loading, high vacuum furnace. The vacuum system consisted of a mechanical roughing pump, a high vacuum diffusion pump, and a liquid nitrogen cold trap. Over time, pressures of $10^{-7}$ torr are obtainable at $2500^{\circ} \mathrm{C}$ with this system. However, during the tests reported here, an average pressure of $4.5 \times 10^{-5}$ torr was achieved over the range of temperatures utilized $\left(200\right.$ to $\left.1200^{\circ} \mathrm{C}\right)$. The vacuum chamber contains a furnace with tungsten heat shields and a water cooled "cold wall" assembly ( $139.7 \mathrm{~mm}$ diameter $\times 285.75 \mathrm{~mm}$ in length). Resistance heating is provided by 
electron-beam-welded semi-cylindrical tantalum mesh elements (split-type, $63.5 \mathrm{~mm} \mathrm{x}$ $203.2 \mathrm{~mm}$ ) with bus-bar heating element leadins.

As shown in Fig. 3, this vacuum furnace system was mounted between the columns of a screw driven Instron Model TT-D-L universal testing machine. Tests were performed at crosshead speeds of $0.02 \mathrm{in} / \mathrm{min}\left(6.67 \times 10^{-4} \mathrm{~s}^{-1} \mathrm{strain}\right.$ rate $), 0.002 \mathrm{in} / \mathrm{min}$ $\left(6.67 \times 10^{-5} \mathrm{~s}^{-1}\right.$ strain rate) and $2.0 \mathrm{in} / \mathrm{min}\left(6.67 \times 10^{-2} \mathrm{~s}^{-1}\right.$ strain rate). Steel universal joints $76.2 \mathrm{~mm}$ long and $31.75 \mathrm{~mm}$ in diameter were used on the top and bottom linkages to maintain optimum alignment. The specimen grips were made out of TZM molybdenum (Mo-0.5Ti-0.1Zr-0.02W), which was selected because of its high recrystallization temperature and excellent creep and tensile strength at high temperatures. The top grip was $127 \mathrm{~mm}$ in length and $22.23 \mathrm{~mm}$ in diameter. The bottom grip was $177.8 \mathrm{~mm}$ in length and $22.23 \mathrm{~mm}$ in diameter. The test specimens were inserted into the slotted (22.23 mm deep $\times 2.46 \mathrm{~mm}$ wide) grips and pinned on both the top and bottom with a $6.22-\mathrm{mm}$ diameter TZM pin.

Two types of Lebow load cells were used to perform the tests and were calibrated prior to use. The sensitivities were: $0.4451 \mathrm{mV} / \mathrm{V} / \mathrm{hb}$. for the 5,000 lb. (Model 3174) load cell and $1.313 \mathrm{mV} / \mathrm{V} / \mathrm{bb}$. for the $500 \mathrm{lb}$. (Model 3173) load cell. The 5,000 lb. rated capacity load cell was used for tests between ambient temperature and $500{ }^{\circ} \mathrm{C}$, and the $500 \mathrm{lb}$. load cell was used for temperatures between $700^{\circ} \mathrm{C}$ and $1200^{\circ} \mathrm{C}$. Load cells were selected based on previous test data which showed that the loads at specific temperatures would not exceed the rated capacity of the selected load cell.

Two type $S$ thermocouples (Pt.-Pt $10 \% \mathrm{Rh}$, range $0^{\circ} \mathrm{C}-1768^{\circ} \mathrm{C}$ ) were inserted through a vacuum flange and connected with ceramic high temperature mini connectors. The ungrounded 152.4-mm long tantalum sheathed thermocouples (with $\mathrm{BeO}$ insulation) were attached to the tensile specimen using $0.508-\mathrm{mm}$ diameter niobium wire. To ensure continuity and greater accuracy, type $S$ extension wire was used to connect the controlling thermocouple (connected to the Eurotherm 847 controller) and the back-up thermocouple (connected to an Omega DP80 series read out). Should the controlling thermocouple fail, the back-up thermocouple could be easily disconnected from the exterior of the furnace to the Eurotherm controller, thereby preserving the test and avoiding the potential loss of a specimen.

Thermocouples were placed on the top and bottom of the gage section of the tensile specimens approximately $9.53 \mathrm{~mm}$ apart to measure the uniformity of the temperature along the gage section. Temperature profiles along the length of the furnace were performed to quantify these temperature gradients. Gradients in excess of $50^{\circ} \mathrm{C}$ between the thermocouples were measured in some positions. It was found that the most 
uniform temperature could be obtained $\left( \pm 2{ }^{\circ} \mathrm{C}\right.$, depending on the temperature) when the gage section of the specimen was positioned approximately $120.65 \mathrm{~mm}$ from the top portion of the copper clam shell "cold wall" assembly. Tensile testing was performed with the specimens in this position.

Load vs. time data were collected using a Hewlet-Packard data acquisition system. The Data Acquisition/Control Unit (HP-3497A) reads voltages from the Digital Voltmeter (HP-3456A), then an HP-9816 computer was used to convert the raw voltages to load values using the load cell sensitivities given previously. These load values were plotted as a function of displacement, which was computed based on the known crosshead speed and measured elapsed time. These load and displacement measurements were used to calculate and plot the stress vs. strain results. All of the measured load vs. displacement curves were smooth and no yield points were observed. Therefore, yield strengths were calculated using a $0.2 \%$ plastic strain offset from the elastic line. The calculated yield strengths, ultimate tensile strengths, and failure elongations are tabulated in the Appendix.

\section{Results and Discussion}

It can be seen in Figure 4 that the yield strength decreases rapidly with increasing temperature from room temperature to $300^{\circ} \mathrm{C}$. There is a plateau in yield strength between approximately 300 and $600^{\circ} \mathrm{C}$, which includes a slight peak. Such plateaus are commonly observed and are usually attributed to the presence of solutes [5,6]. The yield stress declines sharply for temperatures above $700^{\circ} \mathrm{C}$. As shown in Fig. 4, the results of the present study compare very well to those of Kassner $[1,2,4]$ for a range of quasi-static strain rates.

The temperature dependence of the ultimate tensile strength (UTS) is presented in Figure 5. Again, the UTS decreases rapidly with increasing temperature from room temperature to $300^{\circ} \mathrm{C}$, followed by a plateau and then a rapid decrease in UTS as the temperature increases above about $700^{\circ} \mathrm{C}$. The data of Kassner [4] show similar trends but the plateau in the UTS at $300-700^{\circ} \mathrm{C}$ is less pronounced than in the data of the present study. The more pronounced plateau observed in the present study is most likely caused by small variations in impurity contents. The effects of impurities, particularly interstitital carbon, oxygen and nitrogen, on the behavior of austenitic stainless steels have been well documented [6,7]. Although this hypothesis has not been confirmed, Table 1 shows that the carbon content, in particular, is somewhat higher for the material used in the present work compared with that for the material tested by Kassner. Overall, 
the data of the present study compare well with those of Kassner despite the relatively minor variations in the intermediate temperature strengths.

Figure 6 shows the variation in the elongation to failure as a function of test temperature. The data of the present study exhibit a slight decrease in ductility from ambient temperature to $700^{\circ} \mathrm{C}$, then an increase at the higher temperatures of 1000 and $1200^{\circ} \mathrm{C}$. The data of Kassner [4] also show a decrease in elongation to failure with increasing temperature from ambient temperature to $700^{\circ} \mathrm{C}$. Despite this similarity in trend, the elongation values measured in the present study are larger than those determined by Kassner. The reason for this discrepancy is most likely due to the difference in specimen geometries. The specimens used by Kassner at quasi-static rain rates had a $51-\mathrm{mm}$ gage length with a $6.4-\mathrm{mm}$ diameter. This length-to-diameter ratio of almost 8 is significantly larger than the length-to-width ratio of 2.5 used in the specimens of the present study. Specimens with a long gage length relative to their diameter or width are known to result in measured failure strains less than those obtained with shorter gage length specimens [8].

In addition to the data presented above, room temperature tensile tests of 21-6-9 stainless steel sheet were performed at two additional strain rates: $6.67 \times 10^{-5}$ and $6.67 \mathrm{x}$ $10^{-2} \mathrm{~s}^{-1}$. Figure 7 shows the variation in the yield strength and ultimate tensile strength with strain rate at room temperature. Both of these quantities increase as the strain rate increases. Based on these limited data, the constant structure strain-rate sensitivity at yield, $m$, was computed using:

$$
m=\left(\frac{\partial \log \sigma}{\partial \log \dot{\varepsilon}}\right)_{T, \varepsilon}
$$

where $\sigma$ is the stress, $\dot{\varepsilon}$ is the strain rate, $T$ is temperature and $\varepsilon$ is strain. The $\log (Y S)$ vs. $\log$ (strain rate) data are plotted in Fig. 8, and reveal a strain-rate sensitivity of about 0.034 . This value is consistent with the value of 0.038 determined by Kassner and Breithaupt [2].

\section{Summary and Conclusions}

In an effort to provide data useful to designers and finite-element analysts, the tensile properties of 21-6-9 stainless steel have been measured in vacuum at temperatures between ambient and $1200^{\circ} \mathrm{C}$ at a strain rate of $6.67 \times 10^{-4} \mathrm{~s}^{-1}$. The data show that the 
yield stress decreases rapidly with increasing temperature from room temperature to about $300^{\circ} \mathrm{C}$, followed by a nearly constant value in the "plateau" region from 300 to 600 'C. Beyond the "plateau", there is a more rapid drop in yield stress. The temperature dependence of the ultimate tensile stress shows a plateau between approximately 300 and $700^{\circ} \mathrm{C}$, which may be caused by the presence of interstitial solutes. 21-6-9 stainless steel has excellent ductility, ranging from 55 to $95 \%$ elongation to failure. It appears that there is a local minimum in the ductility at approximately $700^{\circ} \mathrm{C}$.

The results from this investigation have been compared with the earlier results of Kassner. Overall, the data compare favorably, though somewhat more pronounced solute effects and higher ductilities were measured in the present study. Small differences in the alloy composition are believed to have caused the former, while the latter is attributed to the use of shorter gage length specimens in the present study.

Finally, the room temperature constant structure strain-rate sensitivity exponent at yield was found to be quite low at quasi-static strain rates, as in many alloys. The value measured in the present investigation was 0.034 , which is consistent with the value of 0.038 measured by Kassner and Breithaupt [2].

\section{Acknowledgments}

The authors wish to acknowledge the financial support and technical guidance provided by Dr. James Hanafee. Helpful comments on the manuscript by Gil Gallegos and metallography by Bob Kershaw also are gratefully acknowledged. 


\section{References}

1. M. E. Kassner, "Variation of the Yield Strength and Strain-Rate Sensitivity Exponent of Type 21-6-9 Stainless Steel over a Wide Temperature Range," University of California, Lawrence Livermore Laboratory Report No. UCID-19597 (1982).

2. M. E. Kassner and R. D. Breithaupt, "The Yield Stress of Type 21-6-9 Stainless Steel Over a Wide Range of Strain-Rate $\left(10^{-5}\right.$ to $\left.10^{4} \mathrm{~s}^{-1}\right)$ and Temperature," Int. Phys. Conf. Ser. No. 70, 47-54 (1984). Also University of California, Lawrence Livermore Laboratory Report No. UCID-19818 (1983).

3. M. E. Kassner, "A Simple Constitutive Equation to Model the Low Temperature Yield Strength of Type 21-6-9 Stainless Steel," J. Engng. Mater. Technol., 105, 231-233 (1983).

4. M. E. Kassner, Unpublished research, Lawrence Livermore National Laboratory (1982).

5. G. A. Henshall and A. K. Miller, "The Influence of Solutes on Flow Stress Plateaus, with Emphasis on Back Stresses and the Development of Unified Constitutive Equations," Acta Metall. 37, 2693-2704 (1989).

6. C. G. Schmidt and A. K. Miller, "The Effect of Solutes on the Strength and Strain Hardening Behavior of Alloys," Acta Metall. 30, 615-625 (1982).

7. C. G. Schmidt and A. K. Miller, "A Unified Phenomenological Model for Non-Elastic Deformation of Type 316 Stainless Steel - Part II: Fitting and Predictive Capabilities," Res Mechanica 3, 175-193 (1981).

8. Metals Handbook, 9th ed., vol. 8, ASM International, Metals Park, OH (1984). 


\section{Appendix: Tabulated Data}

\begin{tabular}{|c|c|c|c|c|c|}
\hline Temp. $\left({ }^{\circ} \mathrm{C}\right)$ & YS (ksi) & $Y S(\mathrm{MPa})$ & UTS (ksi) & $\mathrm{UTS}(\mathrm{MPa})$ & \% Elongation \\
\hline 20. & 48.80 & 336.46 & 102.40 & 706.02 & 72.69 \\
\hline 300 & 24.64 & 169.89 & 78.55 & 541.58 & 68.87 \\
\hline 500 & -..--..- & -........ & 72.90 & 502.63 & 70.84 \\
\hline 500 & 24.00 & 165.47 & 77.10 & 531.59 & 66.42 \\
\hline 500 & 26.76 & 184.50 & 77.10 & 531.59 & 64.40 \\
\hline 700 & 21.40 & 147.55 & -...-..-- & -........ & -.-....- \\
\hline 700 & 19.78 & 136.38 & 62.70 & 432.30 & 53.30 \\
\hline 700 & 18.77 & 129.41 & 66.20 & 456.43 & 66.20 \\
\hline 1000 & 11.88 & 81.91 & 15.36 & 105.90 & 88.83 \\
\hline 1200 & 4.37 & 30.13 & 4.89 & 33.72 & 92.90 \\
\hline
\end{tabular}




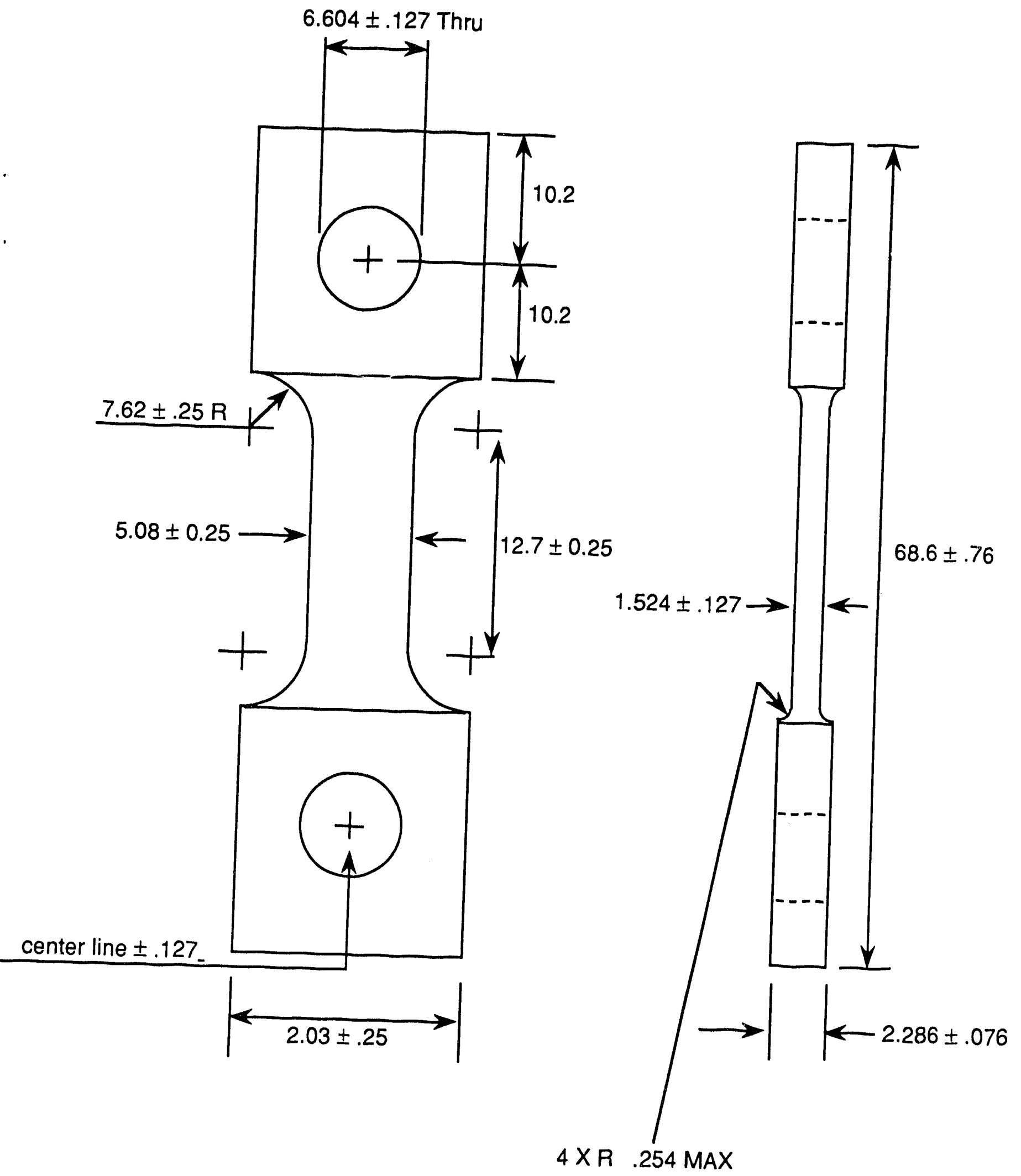

Figure 1. Schematic illustration of the specimen geometry used to evaluate the tensile properties of 21-6-9 stainless steel sheet. All dimensions are in mm. 


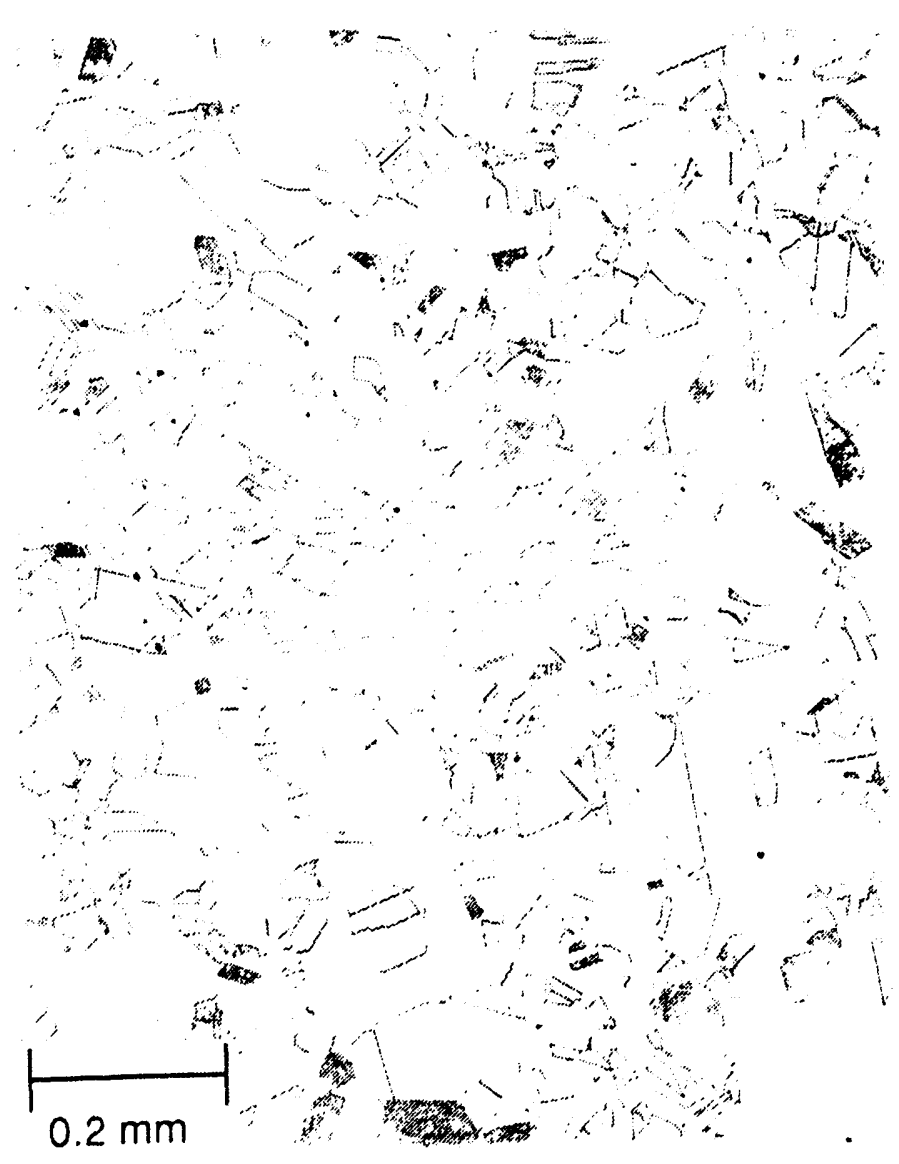

Figure 2. Optical micrograph of 21-6-9 stainless steel following annealing at $1070^{\circ} \mathrm{C}$ for one hour. 


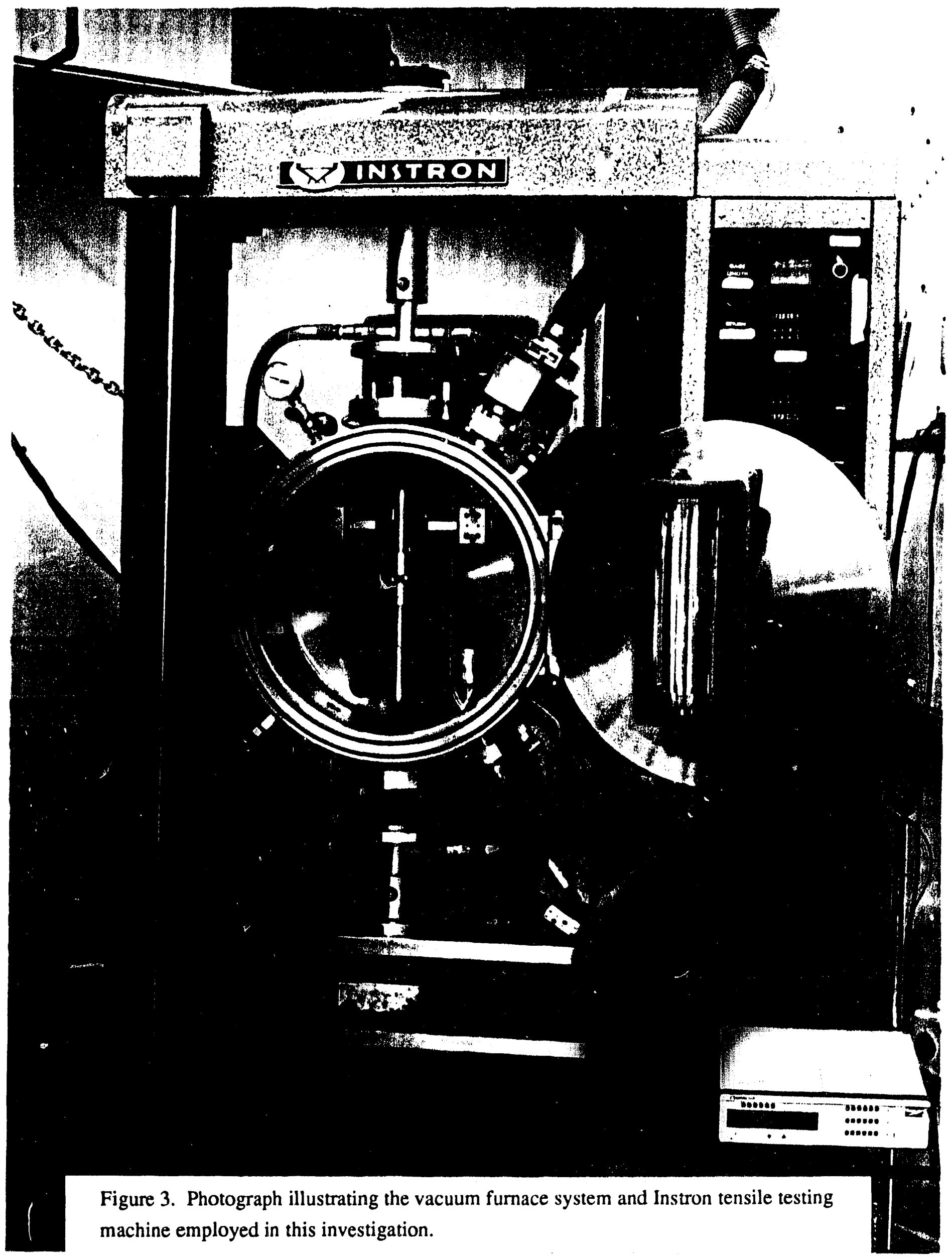




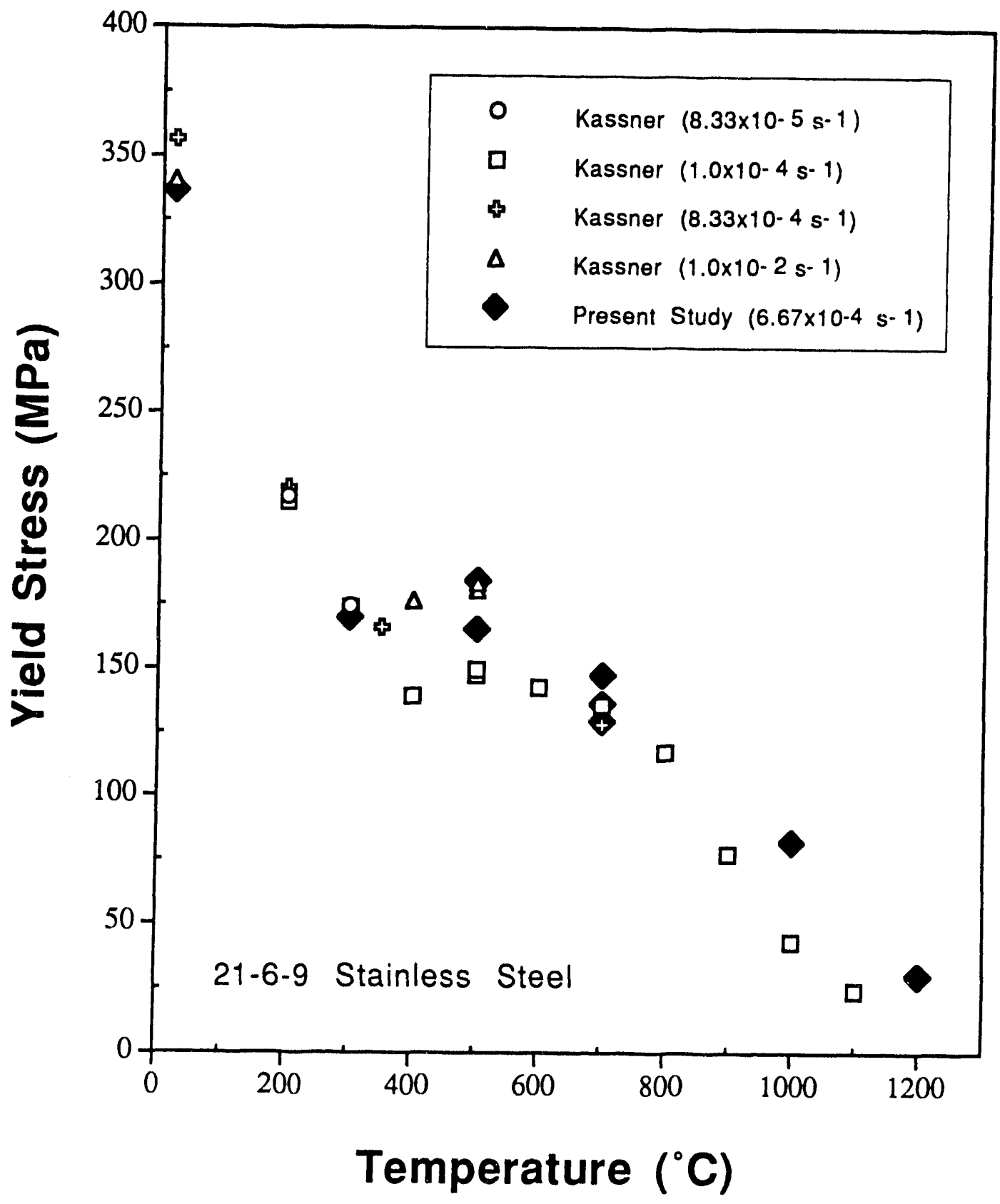

Figure 4. The temperature dependence of the yield stress measured at a strain rate of $6.67 \times 10^{-4} \mathrm{~s}^{-1}$ is compared with that measured by Kassner $[1,2,4]$ over a range of quasi-static strain rates. 


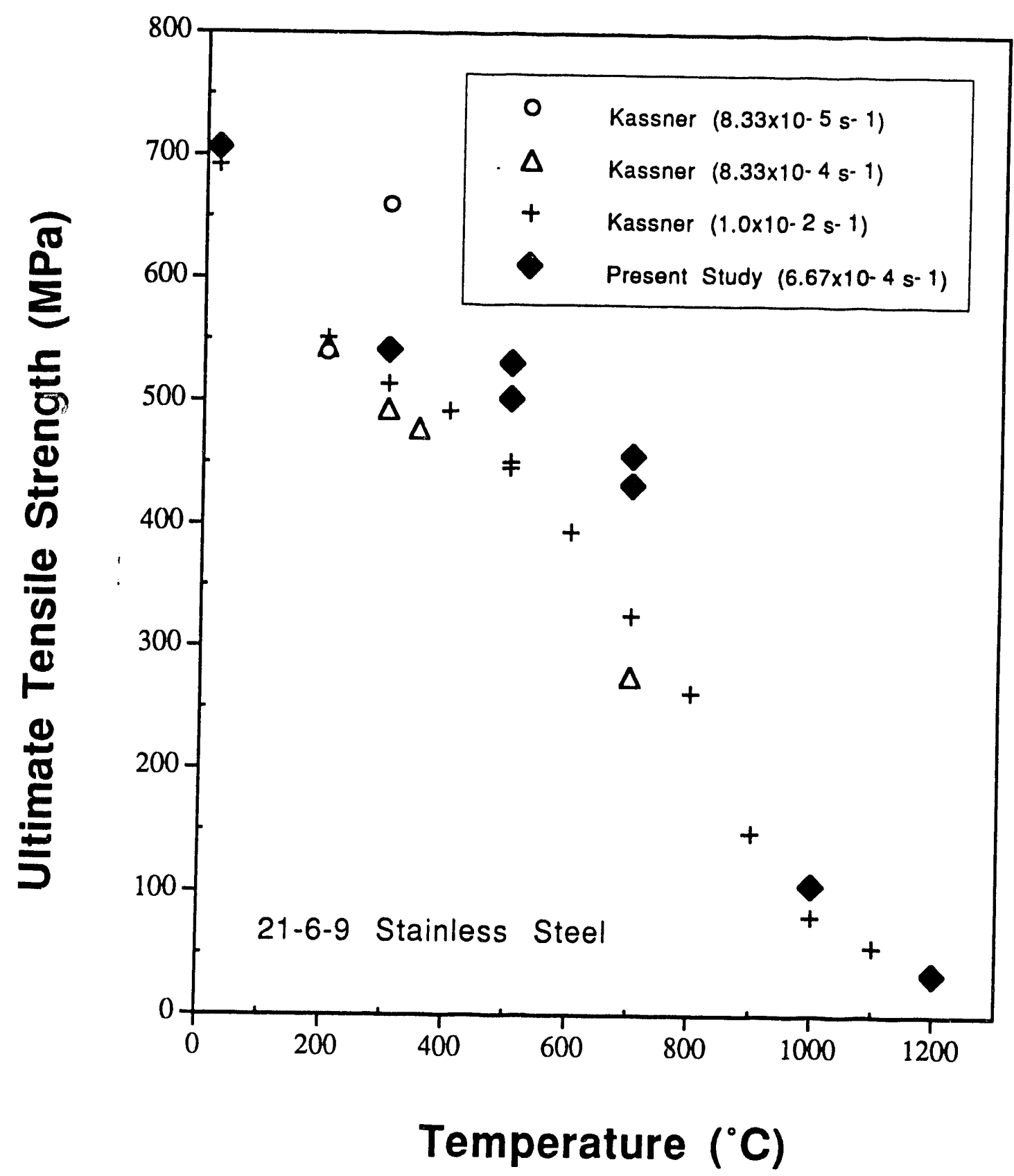

Figure 5. The temperature dependence of the ultimate tensile stress measured at a strain rate of $6.67 \times 10^{-4} \mathrm{~s}-1$ is compared with that measured by Kassner [4] over a range of quasi-static strain rates. 


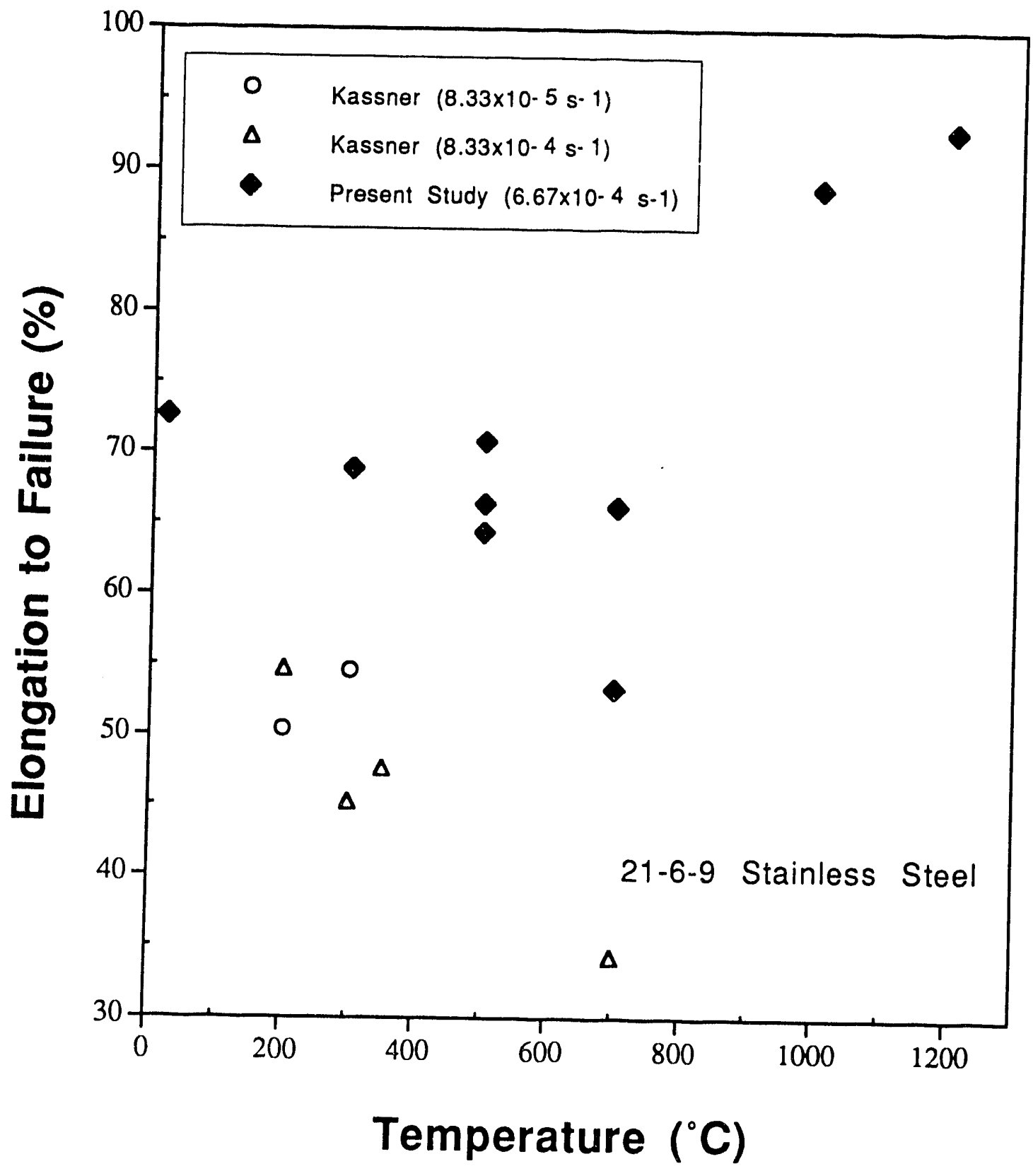

Figure 6. The temperature dependence of the elongation to failure measured at a strain rate of $6.67 \times 10^{-4} \mathrm{~s}-1$ is compared with that measured by Kassner [4] at two quasi-static strain rates. 


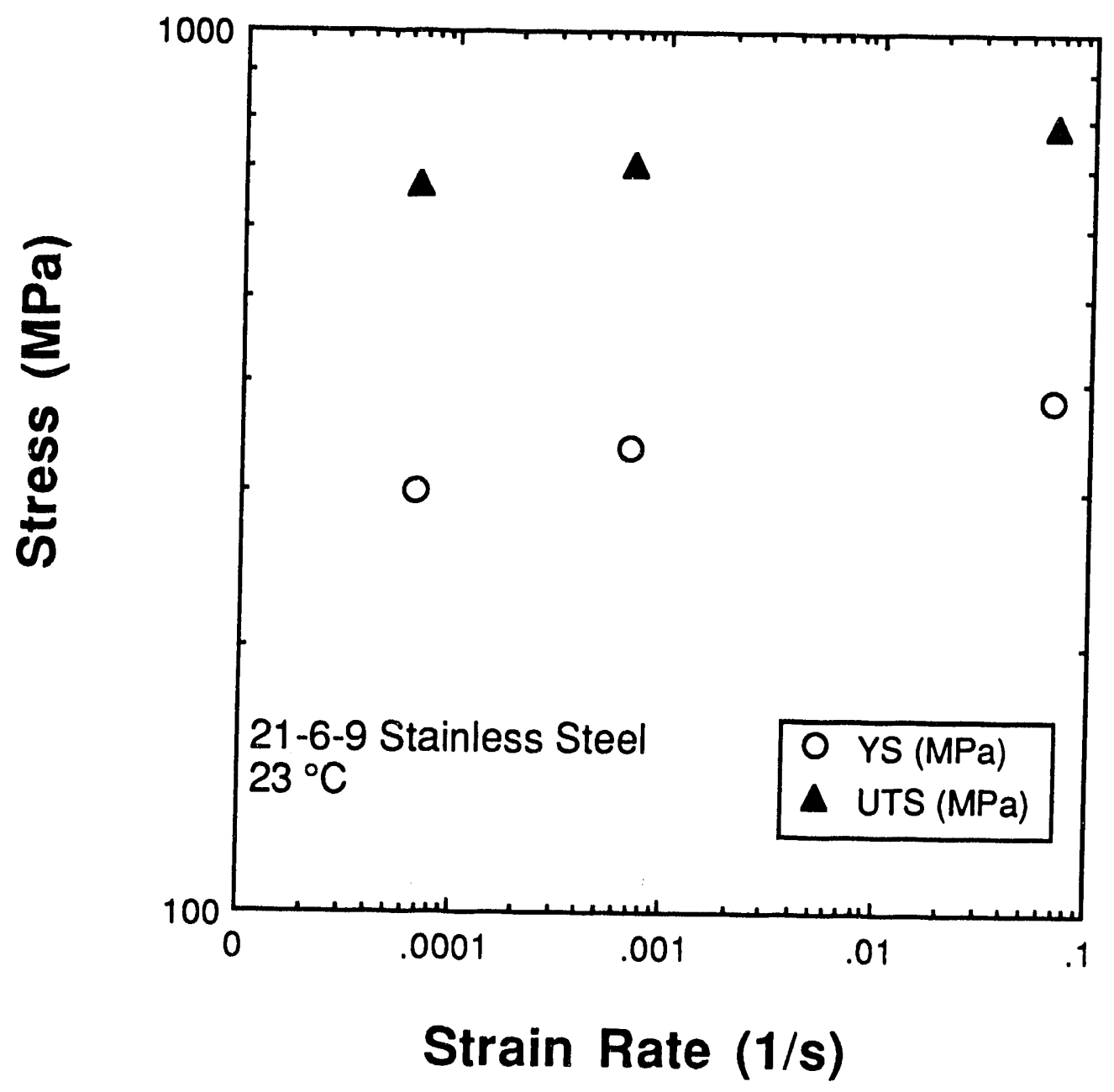

Figure 7. The variation in the room temperature yield and ultimate tensile stresses with strain rate for 21-6-9 stainless steel. 


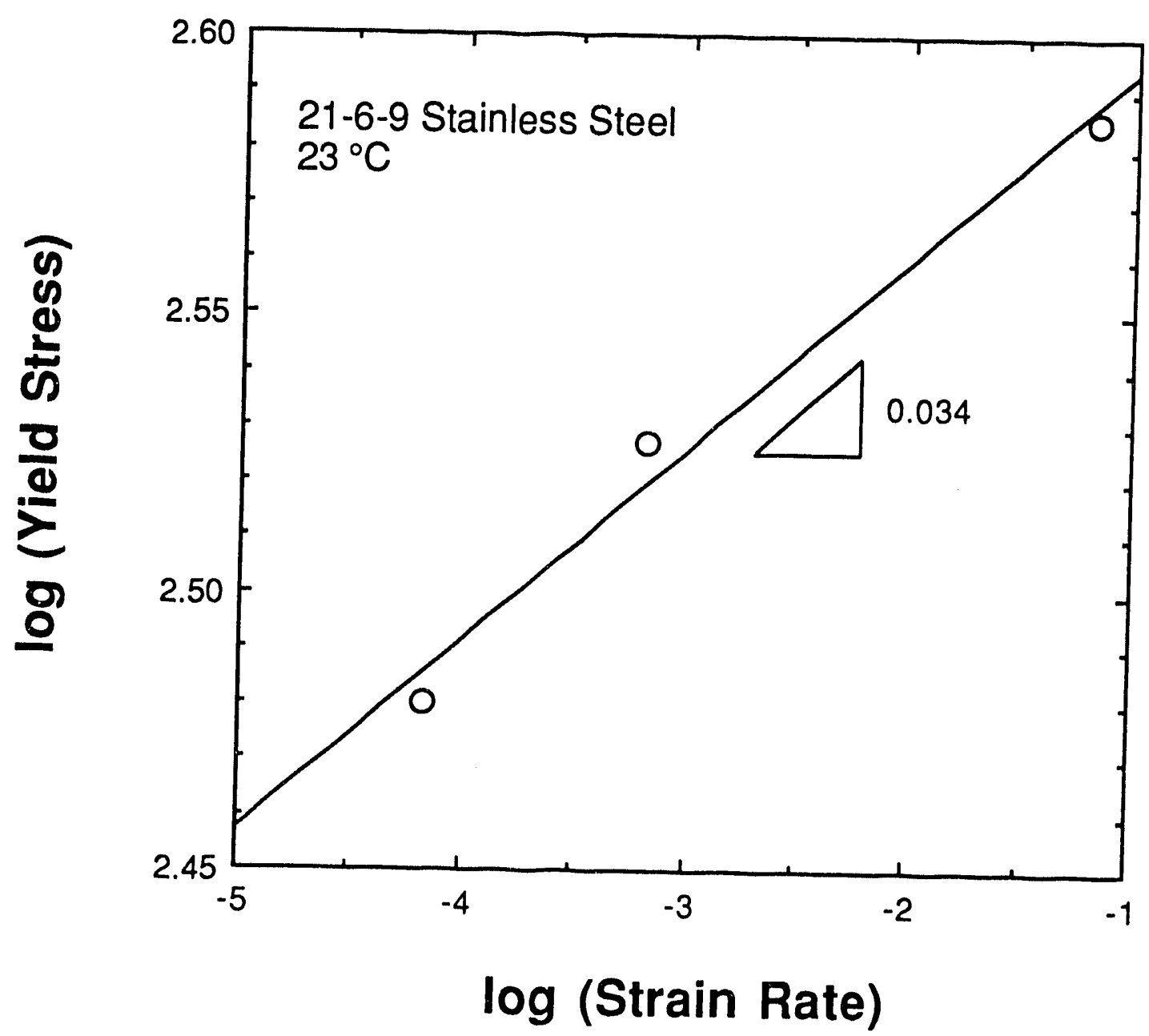

Figure 8. The yield stress as a function of strain rate for 21-6-9 stainless steel tested at ambient temperature, showing a strain-rate sensitivity of approximately 0.034 . 


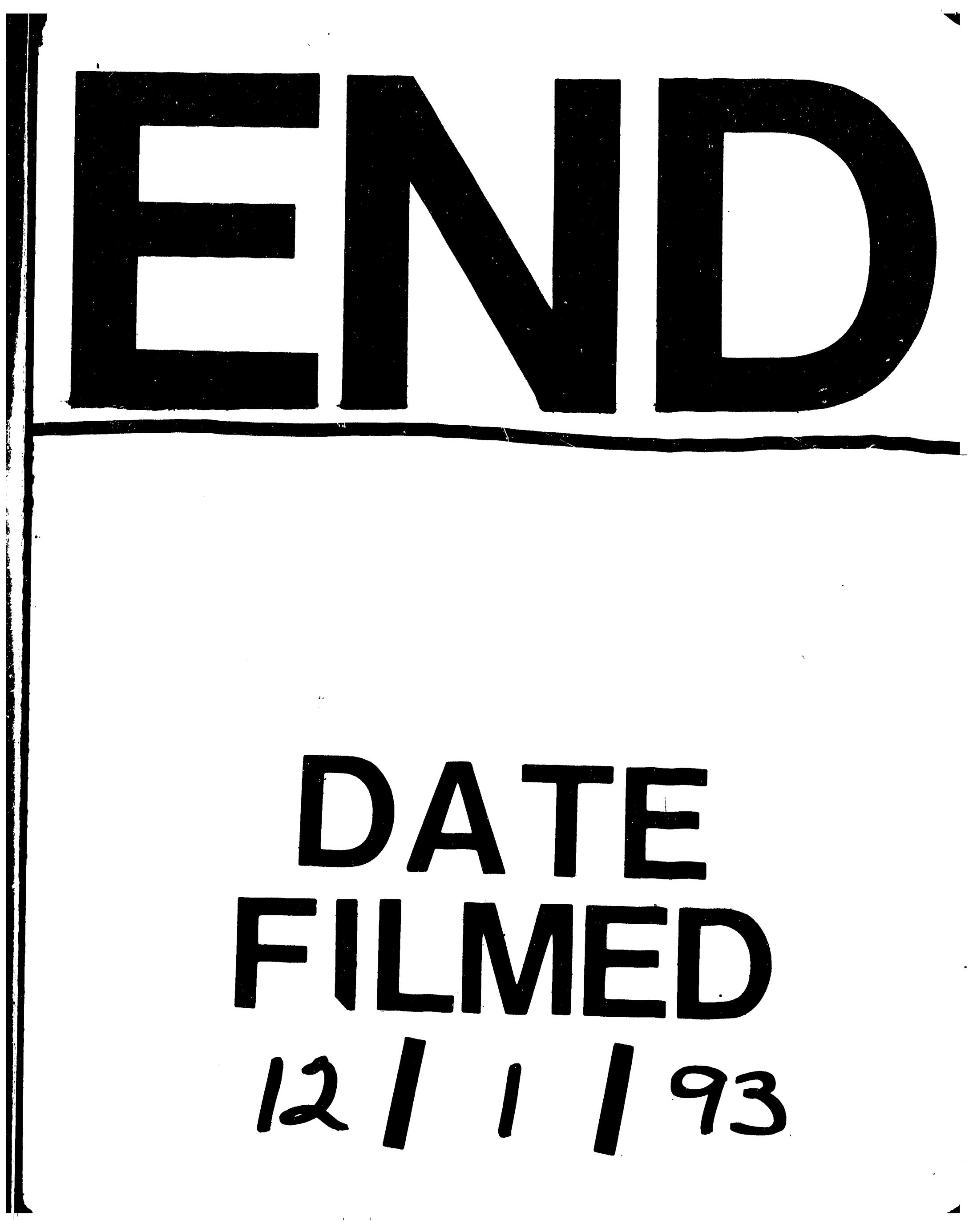





